\title{
EFL CRITICAL READING SYLLABUS AND MATERIALS FOR STUDENTS OF THE ENGLISH DEPARTMENT
}

\author{
${ }^{\# 1}$ Fathurrahman Imran, ${ }^{* 2}$ Heri Hidayatullah \\ ${ }^{\# 1}$ English Lecturer, FBMB, UNDIKMA, Indonesia \\ ${ }^{* 2}$ English Lecturer, FBMB, UNDIKMA, Indonesia
}

Corresponding Author Email: fathurrahmanimran@ikipmataram.ac.id

\begin{abstract}
A B S T R A C T S
The demand of a new model of syllabus and materials were implicitly required through the launching of KKNI-based Curriculum in Indonesia. Due to, finding the students' needs and learning characteristic as the main consideration in developing them became the purpose of this current research. A qualitative research had been conducted to get the data needed by which two kinds of questionnaires were administered then analyzed qualitatively (Likert scale). The respondents involved were 132 students and the results dealt with the learning characteristics showed that the audio was $19.69 \%$, the visual was $50.75 \%$, and kinaesthetic was $29.54 \%$. In relation to the students' needs (four aspects), 1) necessities on topic interest like education (72\%), culture (63\%), and social life (45\%); 2) background knowledge was categorized into good (57.25\%), very good $(28 \%)$, and not good $(14.75 \%) ; 3)$ critical reading goals for both core and sub-skills very agree $(42.71 \%)$, agree $(30.14 \%)$, and not agree (27.14\%); and 4) learning model tended the cooperative (27.25 very agree), (35.5 agree), (37.25 not agree). Thus, it could be concluded that the students' learning style dominantly in visual way with cooperative learning model. In addition, the students were eager to have critical reading skills with sufficient prior knowledge but the topic is mostly in the area of education. It is recommended that in developing the syllabus and materials, the lecturers should consider both students' characteristics and needs.
\end{abstract}

\begin{tabular}{l}
\hline A R T I C L E I N F O \\
\hline Article History: \\
Received: May, 2020
\end{tabular}

Revised: June, 2020

Published: June, 2020

\begin{tabular}{l}
\hline Keywords: \\
KKNI, \\
Critical reading, \\
Syllabus, \\
Material,
\end{tabular}

Keywords:

Critical reading,

Material,

How to cite: Imran, F., \& Hidayatullah, H. (2020). EFL Critical Reading Syllabus and Materials for Students of the English Department. Jo-ELT (Journal of English Language Teaching) Fakultas Pendidikan Bahasa \& Seni Prodi Pendidikan Bahasa Inggris IKIP, 7(1), 51-56. doi:https://doi.org/10.33394/jo-elt.v7i1.2747

\section{INTRODUCTION}

A word 'critical' does not have negative meaning in any context but it is closest to 'evaluative' or 'reflection'. Furthermore, in the context of reading argumentative text, it refers to evaluate conclusion before making decision. Olarak, D. (2014) gave the feature of critical as in words choice of oral and written. Next to that, this kind of feature can affect the relationship according to a proverb "your mouth is your swords".

In accordance to the market demand, it is no doubt that Critical Reading skills is paramount. There are two general reasons stated by Basri (2013) why ones must be critical, firstly because of various types of information received including its source and essence, secondly the students must be provided with a sufficient ability to think in order that they can improve themselves on their own disciplines. Cahyono, B. Y., \& Widiati, U. (2006) showed its importance through reading instruction by which the students are required to be able to understand how writing persuades, and to determine whether one should accept or reject the 
idea of text, after analyzing, synthesizing, and evaluating it (Andreani, 2010). Due to, the reading class participants are able to draw their own conclusion along with logical reason.

Having critical reading skills is not as easy as turning hand over but it requires a good and appropriate plan. In the university level, the lecturers' plan is usually reflected in the form of syllabus. The format of the syllabus can be taken from the guidelines published by the ministry of Research and Technology. The key point of this document is the ability of the practitioners in developing course learning outcomes by which it should refer to the ability of reading critically. In addition, the syllabus is important because of three major roles as contract, permanent record, and learning tool (Parkes, J., \& Harris, M. B. 2002). The absence of this file might lead not to reach the learning goal that had been settled by institution and choose irrelevant teaching materials. Due to, it is assumed that there are a lot of universities not develop this document yet particularly for critical reading course.

Attention to the reading materials must be paid. Suarcaya, P. (2011) Comments 'instructional materials generally serve as the basis of much of the language input that learners receive and the language practice that occurs in the classroom' like vocabulary retention and critical reading profile (Ghajar, S. G., \& Kafshgarsouteh, M. 2011). Next to that, a research found that the use of online audio materials for listening has positive results in terms of learners' enjoyment, interest, and achievement. In addition, the reading materials to be provided should be challenging texts. On this occasion, Errington, A., \& Bubna-Litic, D. (2015) said the textbook could reinforce underdeveloped students' epistemology through limitations of content and position as passive recipients of an authoritative version of oversimplified knowledge'. Thus, having appropriate materials, the students' academic and non-academic purposes can be improved.

It is important to be taken into account that there are some types of textbook, two of them are teachers-made and readymade textbooks. In relation to that, Hutchinson, T., \& Torres, E. (1994) wrote that it is difficult to find out the textbook absolve teachers' responsibility like what and how to teach. To the researchers' opinion, a teacher should create a textbook by himself or herself in order to accommodate the students' needs and characteristics. Due to the aim of this research is to produce a textbook based on needs and characteristics. Suarcaya, P. (2011) uttered the needs is really necessary when the curriculum planners intend to produce English teaching program for special purposes (ESP). In analyzing the learners' needs, it is very important to consider its classification like subjective and objective (Nunan, D. (1999). The former refers to the needs that cannot be observed easily. Meanwhile, the latter can be observed in the form their individual data such as language proficiency and pattern of language use.

\section{RESEARCH METHOD}

The research goal is to produce Critical Reading Syllabus and Textbook based on needs and characteristics. Due to, R \& D proposed by Meredith D. Gall, W. R., \& G, J. P. (2003) becomes the umbrella of the research design. Next to that, the $\mathrm{R} \& \mathrm{D}$ process requires needs analysis-usually in the form of qualitative and or quantitative-as the main consideration in developing such products. Thus, the design of this current research refers to qualitative. There were two questionnaires administered to the respondents and then qualitatively using Liker Scale (Creswell, 2012). The first aimed to obtain the data of the learning characteristics and another one aims to get the data of the respondents' needs on critical reading.

\section{Research Design}

A quasi-experimental research design was applied in this current research since it aims at examining the products (Sugiono 2012, 79). The type of quasi-experiment in this research was post-test only design by which the researchers gave treatment using a certain teaching 
method then administering the critical reading test. In addition, another instrument (questionnaire) was distributed after having the test.

\section{Population and Sample}

Due to the products of this current research will be used at the fourth-semester students of the English Department of Faculty of Language and Art Education IKIP Mataram. Therefore, the subjects will be taken from that institution.

\section{Instruments}

The instruments of this current research were obtained on the basis of the analysis of the collected data firstly derived from two questionnaires.

There were four aspects to be focused on in this part namely the students' necessities on critical reading, weaknesses on critical reading, the objective(s) of teaching critical reading, and the required classroom activities

\section{Data Analysis}

The model of this current research is intended to use the ten major steps of R \& D cycle proposed by Borg and Gall (1983:775). However, the researchers will adapt them in order to be appropriate with their development needs. Due to, the development steps of this current research are 1) early research (needs analysis), 2) development of products, 3) preliminary field-testing, 4) products revision, 5) main field-testing, 6) products revision, and 7) final products.

\section{RESEARCH FINDINGS AND DISCUSSION Research Finding \\ Data on Students' Needs}

There were some aspects recorded and displayed namely necessities, weaknesses, objective(s), and classroom activities.

Table 1

Students' Topic Interest

\begin{tabular}{lccccc}
\hline & \multicolumn{5}{c}{ Percentage } \\
\hline Topic interest & & & & \\
\hline Culture & 63 & 29 & 8 & - \\
\hline Social life & 45 & 49 & 4 & 2 \\
\hline Education & 72 & 28 & - & - \\
\hline Politics & - & 4 & 39 & 57 \\
\hline Law & - & - & 48 & 52 \\
\hline
\end{tabular}

The above table described the students' necessities on critical reading. The first item deals with the topic interest to be discussed during the teaching-learning process. It showed that they were highly interested to talk about culture, social life, and education. However, politics and law did not make them enjoy a discussion. Thus, it could be tabulated that the topics about education (72\%), culture (63\%), and social life $(45 \%)$.

Table 2

Students' Background Knowledge

\begin{tabular}{lcccc}
\hline \multicolumn{1}{c}{ Items } & & & & \\
\hline Critical reading prerequisites & 39 & 54 & 7 & 0 \\
\hline Reading Comprehension I & 31 & 56 & 10 & 3 \\
\hline Reading Comprehension II & 23 & 48 & 21 & 8 \\
\hline Reading Comprehension III & 19 & 71 & 5 & 5 \\
\hline Extensive Reading & 28 & 57.25 & 10.75 & 4 \\
\hline Percent & & & & \\
\hline
\end{tabular}


The table 2 showed the students' current reading ability were mostly in a good level (57.25) and followed by very good (28). However, in not good level was 14.75 and therefore these categories were reflected from the score obtained. Moreover, the highest percentage fell on the Extensive Reading course. Thus, only a few of them who were in not good and not very good score.

Table 3

Students' Perception on the Critical Reading Objectives

\begin{tabular}{|c|c|c|c|c|}
\hline Items & \multicolumn{4}{|c|}{ Percentage } \\
\hline \multicolumn{5}{|l|}{ Non sub-skills goals } \\
\hline Vocabulary mastery & 25 & 48 & 13 & 14 \\
\hline Writing skills & 39 & 32 & 19 & 10 \\
\hline Grammar mastery & 16 & 22 & 44 & 18 \\
\hline \multicolumn{5}{|l|}{ Sub-skills goals } \\
\hline Knowing the English texts organization & 21 & 38 & 40 & 1 \\
\hline $\begin{array}{l}\text { Producing new ideas in the form of spoken and } \\
\text { written }\end{array}$ & 48 & 31 & 13 & 8 \\
\hline Synthesizing others ideas & 71 & 21 & 8 & 0 \\
\hline Drawing good logical conclusion & 79 & 19 & 2 & 0 \\
\hline
\end{tabular}

The table 3 showed the students' expectation on vocabulary mastery was quite higher along with the writing skills (73\%) than grammar mastery $(62 \%)$. In another part, the subskills was highly expected by the students.

Table 4

Students' Expectation on Classroom Model

\begin{tabular}{lccccc}
\hline Items & \multicolumn{4}{c}{ Percentage } \\
\hline Self-working & 18 & 22 & 33 & 27 \\
\hline Work in pair & 36 & 64 & 0 & 0 \\
\hline Work in small group & 48 & 52 & 0 & 0 \\
\hline Work in large group & Percent & 7 & 4 & 67 & 22 \\
\hline & Prour & 27.25 & 35.5 & 25 & 12.25 \\
\hline
\end{tabular}

The table 4 showed the teachers' role as the controllers (62\%) was not highly expected. However, the rest of the learning model in classroom were highly positive like organizers $(62 \%)$, collaborators $(100 \%)$, Information providers (100\%), Feedback givers $(100 \%)$, and facilitators $(84 \%)$. Moreover, the data about the students' role shown that they really wanted to be the knowledge informants $(100 \%)$ and providers $(100 \%)$ rather than the knowledge receivers $(30 \%)$.

\section{Data on learning characteristics}

Table 5

Students' Learning Characteristics

\begin{tabular}{ccccc}
\hline \multirow{2}{*}{ Respondents } & \multicolumn{3}{c}{ Types of Learning } & \multirow{2}{*}{ Remarks } \\
\cline { 2 - 4 } & Audio & Visual & Kinesthetic & \\
\hline 132 & 26 & 67 & 39 & - \\
\hline Percent & 19.69 & 50.75 & 29.54 & - \\
\hline
\end{tabular}

The table 5 shows that there were 26 or $19.69 \%$ out of 132 respondents who preferred learning something using picture or other visual media. However, the highest learning style fell on visual $(50.75 \%)$ preferred to learn something through hearing and speaking. Moreover, there were $29.54 \%$ who loved to be given something to accomplish.

\section{Discussion}

It had been elaborated that one of the aspects of needs analysis was dealt with the students' necessities. This kind of aspect focused on finding the students' topic interest to be 
discussed during the teaching-learning process. The researchers found three main topics namely education, culture, and social life. In terms of education, there were $72 \%$ of the students interested on it. That percentage indicated that the dominant materials to be taught and developed was about education followed by culture and social life. In addition, by having the percentage of the three main topics interest, the students were really aware on their future career as the teachers along with their own communication, relationship, and adaptation with their society.

On the basis of the data found, the students' strength was on the prerequisites of critical reading and it indicated that they were ready enough to learn the critical reading skills. However, when they were asked about their current critical reading ability, they had in low category on some sub-skills. Due to the objective(s) of teaching critical reading should cover the whole sub-skills with the required classroom activities.

\section{CONCLUSION}

Regarding the data analysis, the researchers could conclude that the students with visual learning styles were ready enough to learn critical reading and the critical reading syllabus and materials should cover the whole objectives and three topics interest with cooperative learning model.

It is recommended that the future researchers collaborated with the practitioners specifically critical reading lecturers should consider the whole aspects of the students' needs and learning characteristics due to the products (syllabus and materials) that are appropriated for them.

\section{REFERENCES}

Andreani. (2010). Critical Reading. Unpublished Handout. State University of Malang: English Department, Faculty of Letters.

Basri. (2013). Urgensi Melatih Siswa Berfikir Kritis. Mataram: Radar Mandalika.

Cahyono, B. Y., \& Widiati, U. (2006). The Teaching of EFL Reading in the Indonesian Context: The State of the Art. TEFLIN Journal, 17(1), 36-58, www.journal.teflin.org/index.php/journal/article/download/58/52.

Creswell, J. W. (2012). Educational research: Planning, conducting, and evaluating quantitative and qualitative research. Educational Research. New York: Camridge University Press.

Errington, A., \& Bubna-Litic, D. (2015). Management by Textbook. Journal of Management Education, 774-800. https://doi.org/10.1177/1052562915594839.

Ghajar, S. G., \& Kafshgarsouteh, M. (2011). Recovering the Power Inside: A Qualitative Study of Critical Reading in an Iranian University. Turkish Online Journal of Qualitative Inquiry, 2, 26-39, https://files.eric.ed.gov/fulltext/ED537794.pdf.

Hutchinson, T., \& Torres, E. (1994). The Textbook as Agent of Change. ELT Journal, 48(4), 315-328, https://academic.oup.com/eltj/article-abstract/48/4/315/2797673.

Khabiri, M., \& Pakzad, M. (2012). The Effect of Teaching Critical Reading Strategies on EFL Learners Vocabulary Retention. The Journal of Teaching Language Skills (JTLS), 4(1), 73-106. https://doi.org/10.22099/jtls.2012.325.

Meredith D. Gall, W. R., \& G, J. P. (2003). Educational Research: An Introduction (7th Ed). New York: Longman.

Nunan, D. (1999). Second Language Teaching \& Learning. Boston: Heinle \& Heinle Publishers.

Olarak, D. (2014). Critical Reading in EFL Turkish High. International Journal of Language Academy, 2 , https://arastirmax.com/tr/system/files/dergiler/214630/makaleler/2/3/arastirmaxcritical-reading-efl-turkish-high-school-context.pdf. 
Parkes, J., \& Harris, M. B. (2002). The Purposes of a Syllabus. College Teaching, 50(2), 5561. https://doi.org/10.1080/87567550209595875.

Suarcaya, P. (2011). WEB-BASED AUDIO MATERIALS FOR EFL. TEFLIN Journal, 22(1), 59-71. https://dx.doi.org/10.15639/teflinjournal.v22i1/59-71. 